\title{
The Enhancement of Mathematical Creative Thinking and Logical Thinking Ability, and Student Habits of Mind in Junior High School Through ASSURE Learning Model
}

\author{
Nosep Sumiarto $^{1}$, Endang Cahya M A ${ }^{2}$, B A P Martadiputra ${ }^{3}$ \\ \{nosepsumiarto92@gmail.com ${ }^{1}$ \} \\ Program Studi Pendidikan matematika, Sekolah Pascasarjana Universitas Pendidikan Indonesia, Jl. \\ Dr. Setia Budhi No. 229, Bandung 40154, Indonesia ${ }^{1,2,3}$
}

\begin{abstract}
The purpose of the study is to analyze the enhancement of creative thinking and logical thinking ability through ASSURE learning model with used a problem-based learning method. The research design is pretest-posttest with experimental and control class. The research data was obtained using a test of creative and logical thinking skills. The results of the study show that; (1) based on overall and high initial mathematical abilities, the enhancement mathematical creative thinking ability of students who obtained ASSURE learning model is significantly higher than students who obtain conventional learning. (2) Based on overall and the initial mathematical abilities (low, medium and high), the enhancement mathematical logical thinking ability of students who obtained ASSURE learning model is significantly higher than students who obtain conventional learning. (3) Students habits of mind who obtained ASSURE learning model are better than students who obtained conventional learning.
\end{abstract}

Keywords: Creative thinking, Logical thinking, habits of mind, ASSURE learning model

\section{Introduction}

One of the purposes of mathematics education is that students can creative thinking. Creative thinking is a unique human brain activity that can consider, use different perspectives, find many ways and alternatives and produce new things $[1,2]$. Creative thinking ability is very important in daily activities such as modifying or creating an innovation useful for himself and life in society. However, the mathematics creative thinking ability of junior high school students is still low. One phenomenon often occurs in schools is a low of student creativity [3]. The research result of Munahefi et al and Istiqomah et al showed that student mathematics creative thinking ability in junior high school on aspect originality was still low [4, 5]. Furthermore, the research results of Ersory and Baser show that the improvement of students' creative thinking abilities on aspects flexibility and originality is still low [6]. Students are not creative in providing solutions problems and less creative in finding solutions from various book sources $[7,8]$. Based on these explanations, Students' mathematics creative thinking ability in junior high school is very important to improve.

Furthermore, another cognitive aspect that needs to be developed is the logical thinking ability. Logical thinking is an aspect of Piaget's cognitive development that arises in the concrete 
pre-operational and operational periods. Logical thinking is the ability to conclude according to the rules of logic, be able to prove the truth, have the characteristics of thought wrinkles, the ability to argue, and conclude solving problems [9]. Logical thinking ability is needed by students' when taking conclusions in solving a problem, especially in mathematics that learns it needed logical thinking. However, students' logical thinking abilities are still low. This is seen from the low student learning outcomes, one ability that is closely related to student learning outcomes is the ability to think logically [10]. Based on results study of Andriawan and Budiarto's on junior high school students, it shows that students who medium mathematical problem-solving abilities are showing logical thinking skills capable of thinking coherently, can provide arguments and are able to give conclusions but are less precise, and students who have low mathematical problem-solving abilities show the characteristics of thinking logically able to think coherently, unable to provide arguments and conclusions [11]. Based on these explanations, students' logical thinking ability is an essential ability that is important to be improved.

In addition to cognitive aspects, students' affective aspects also need to be developed. One of the affective aspects that supports students' mathematics creative and logical thinking abilities is habits of mind. Habits of mind are intelligent habits in thinking to solve a problem that is a combination of a variety of skills, attitudes, cues, and experience. [12]. Habits of mind have an impact on mathematics ability of $40 \%$ [13]. So, habits of mind are one of the most important affective aspects to support the ability to solve problems in mathematics. However, Students' mathematics habits of mind in junior high school students are still low. Based on the results study Septianawati shows that the achievement students habits of mind in junior high school is still lack [14]. Students' mathematical habits of mind are still not well developed in the mathematics learning process due to the lack of giving problems to students [13]. Based on the results of these explanations, it can be said that students' mathematical habits of mind are still low and need to be developed.

The low ability of creative thinking, logical thinking and students mathematical habits of mind due to inappropriate in choosing learning strategies that are still teacher-centered learning so that students' thinking abilities are less developed $[13,15,16]$. Teacher-centered learning will produce students who lack self-awareness, critical thinking, creative, independent, and less communicative in the learning environment as well as on society [16]. Therefore, the learning process must involve students so that creative thinking ability, logical thinking ability and mathematical habits of mind develop. Furthermore, the learning process must pay attention to the characteristics of students, the use of media and learning technology [17]. One learning model that involves this is the ASSURE learning model. ASSURE learning model is a process of stages in teaching in the class introduced by Smaldino et al which has six stages, namely; The first stage is to analyze learner, the second stage is state standards and objectives, the third stage is select methods, media, and materials, the fourth stage is utilizing media and materials, the fifth stage requires learner participation and the sixth stage is evaluate and revise [18]. Furthermore, Smaldino et al mentioned that several approaches support the ASSURE learning model, namely problem-based learning, guided discovery models and project-based learning [18]. The learning approach used in this study is problem-based learning. Students are faced with a problem that requires students to creative thinking and uses their logical thinking in solving problems so that student habits of mind is trained. Therefore, this research will analyze the enhancement of mathematical creative thinking and logical thinking ability, and student habits of mind in junior high school through ASSURE learning model. 


\section{Method}

This research approach is quantitative by using a quasi-experimental method. The research design is a pretest-posttest with experimental and control classes. The subjects of this study were seventh-grade students in one of the junior high schools in Lembang, West Bandung. The research sample consisted of two classes, namely the experimental and control classes. An experimental class of 30 students used the ASSURE learning model with a problem-based learning approach. The initial mathematical ability category of students consisted of 11 low, 8 medium and 11 high. Meanwhile, the control class of 33 students used scientific learning. categories of students' initial mathematical abilities consisted of 11 low, 15 medium and 7 high.

There are six stages in this research. First, analyze student characteristics. Second, analyze students' initial mathematical abilities (prerequisite material). Third, do the pretest creative and logical thinking ability. Fourth, the implementation of learning. Fifth do posttests of creative thinking, logical thinking ability, and provide mathematical habits of mind questionnaire. Last, analyze the research data.

The teaching material used in this study is rectangles and triangles. Researchers make materials and learning plans tailored to the use of learning models used in the experimental and control classes. Besides, researchers create student activity sheets which are then used by students who function to practice creative and logical thinking skills as well as students mathematical habits of mind in a class.

Next, research data from both classes were analyzed by statistical tests. The data tested is an enhancement score in the ability to think creatively and logically both classes based on overall or based on the category of students' initial mathematical abilities. The last, analyzing the results of the scale Likert scores by statistical tests.

\section{Results and Discussion}

\subsection{Mathematical Creative Thinking Ability}

The following are descriptive data on the results of the pre-test, post-test, and enhancement of students mathematical creative thinking ability on both classes (see Table 1).

In general, table 1 shows mean score of students' creative thinking ability both classes based on overall and initial mathematical abilities categories (low, medium and high) showed a score that is almost the same. However, after being given different treatment on two classes mean score of posttest based on overall and initial mathematical abilities categories (low, medium and high) showed differently. Similarly, enhancement students' mathematical creative thinking abilities based on the overall conventional class mean score of 0.22 and ASSURE learning model class mean score of 0.37 and based on initial mathematical abilities categories (low medium and high) both classes show mean scores in rating 0.18 to 0.44 . Furthermore, statistical tests are needed to find out which class is significantly higher both overall and by initial mathematical abilities category (see Table 2). 
Table 1. The description of mathematical creative thinking ability results.

\begin{tabular}{ccccccccc}
\hline \multirow{3}{*}{ Class } & \multirow{2}{*}{$\begin{array}{c}\text { Category of initial } \\
\text { mathematical ability }\end{array}$} & $\begin{array}{c}\text { Number } \\
\text { of }\end{array}$ & \multicolumn{2}{c}{ Pre-test } & \multicolumn{2}{c}{ Post-test } & \multicolumn{2}{c}{ Enhancement } \\
\cline { 3 - 8 } & Students & Mean & SD & Mean & SD & Mean & SD \\
\hline \multirow{4}{*}{ ASSURE } & Overall & 30 & $\mathbf{7 , 9 3}$ & $\mathbf{3 , 3 3}$ & $\mathbf{1 9 , 6 7}$ & $\mathbf{6 , 1 3}$ & $\mathbf{0 , 3 7}$ & $\mathbf{0 , 1 5}$ \\
& Low & 11 & 6,73 & 3,13 & 4,86 & 4,86 & 0,27 & 0,11 \\
& Medium & 8 & 8,36 & 3,21 & 3,46 & 3,46 & 0,21 & 0,12 \\
& High & 11 & 8,82 & 3,55 & 5,55 & 5,55 & 0,44 & 0,13 \\
& Overall & 33 & $\mathbf{7 , 9 7}$ & $\mathbf{5 , 7 8}$ & $\mathbf{1 6 , 6 4}$ & $\mathbf{5 , 1 6}$ & $\mathbf{0 , 2 2}$ & $\mathbf{0 , 1 7}$ \\
& Low & 11 & 7,91 & 4,74 & 15,27 & 5,10 & 0,20 & 0,10 \\
& Medium & 15 & 7,53 & 5,14 & 17,67 & 5,38 & 0,25 & 0,21 \\
& High & 7 & 9 & 8,79 & 16,57 & 5,00 & 0,18 & 0,18 \\
\hline
\end{tabular}

Table 2. The statistical test results of differences enhancement mathematical logical thinking ability.

\begin{tabular}{cccc}
\hline $\begin{array}{c}\text { Category of initial } \\
\text { mathematical ability }\end{array}$ & Test Statistic & $\begin{array}{c}\text { Sig. }(1- \\
\text { tailed })\end{array}$ & Interpretation \\
\hline Overall & t-test & 0,010 & $\mathrm{H}_{0}$ rejected \\
Low & t-test & 0,062 & $\mathrm{H}_{0}$ accepted \\
Medium & t-test & 0,313 & $\mathrm{H}_{0}$ accepted \\
High & t-test & 0,002 & $\mathrm{H}_{0}$ rejected \\
\hline
\end{tabular}

Based on Table 2 above obtained sig.(1-tailed) value based on overall is 0.010 with the interpretation of $\mathrm{H}_{0}$ rejected. That means, that the enhancement of students' mathematical creative thinking abilities based on overall in the class obtain ASSURE learning model is significantly higher than students obtain conventional learning. The high enhancement mathematical creative thinking ability in ASSURE class is due to the use of problem-based learning, media and technology and to activate student involvement. This result is supported by Ersory and Baser that problem-based learning can improve creative thinking abilities [6]. The use of media and technology has the potential to help improve mathematical creative thinking abilities $[19,20]$. Discussion and interacting is a process of socialization with the surrounding environment can develop one's creativity [21].

Furthermore, based on low and medium initial mathematical ability category was obtained sig. (1-tailed) values more than alpha $(0.05)$ so that $\mathrm{H}_{0}$ is accepted. It shows that the enhancement of students' mathematical creative thinking abilities who obtain ASSURE learning model is not significantly higher than the classroom control on the category of low and medium initial mathematical ability. Meanwhile, based on the category of high initial mathematical ability sig (1-tailed) value of 0.002 is less than alpha so $\mathrm{H}_{0}$ is rejected. That means that enhancement students' mathematical creative thinking abilities at high initial mathematical ability who obtain ASSURE learning model is significantly higher than control class. The enhancement of mathematical creative thinking ability higher significantly occurs in categories of high initial mathematical ability only, because creative thinking ability is a higher-level thinking ability. So, to develop creative thinking ability requires good initial experience and knowledge. According to Bringula et all stated that one of the factors affect learning success was the student's initial ability or the prerequisite material he had learned [22]. The results of this study indicate that ASSURE learning model can improve mathematical creative thinking based on overall and high initial mathematical abilities category. 
There are four indicators of creative thinking ability. First is fluency, namely to spark lots of ideas. Second is flexibility, namely to produce more than one different answer. The third is elaboration, namely detailing or modifying an object. Fourth is originality, namely giving birth to new ideas or ideas. Of the four indicators, the highest average score of enhancement is an indicator of originality in class that obtains the ASSURE learning model. Meanwhile, the average score of the lowest enhancement is an indicator of flexibility in class that obtains conventional learning.

\subsection{Mathematical Logical Thinking Ability}

The following are descriptive data on the results of the pre-test, post-test, and enhancement of students mathematical logical thinking ability on both class (see Table 3).

Table 3. The description of mathematical logical thinking ability results.

\begin{tabular}{ccccccccc}
\hline \multirow{2}{*}{ Class } & $\begin{array}{c}\text { Category of initial } \\
\text { mathematical } \\
\text { ability }\end{array}$ & $\begin{array}{c}\text { Number } \\
\text { of } \\
\text { Students }\end{array}$ & Mean & SD & Mean & SD & Mean & SD \\
\cline { 3 - 8 } ASSURE & Overall & 30 & $\mathbf{7 , 3 3}$ & $\mathbf{3 , 2 5}$ & $\mathbf{1 6 , 2 7}$ & $\mathbf{4 , 9 8}$ & $\mathbf{0 , 4 1}$ & $\mathbf{0 , 1 8}$ \\
& Low & 11 & 6,82 & 2,99 & 15,09 & 4,57 & 0,36 & 0,16 \\
& Medium & 8 & 6,25 & 2,44 & 14,13 & 3,14 & 0,34 & 0,07 \\
& High & 11 & 8,91 & 3,62 & 19,00 & 5,53 & 0,50 & 0,21 \\
& Overall & 33 & $\mathbf{7 , 4 6}$ & $\mathbf{1 , 8 7}$ & $\mathbf{1 2 , 8 5}$ & $\mathbf{2 , 4 6}$ & $\mathbf{0 , 2 4}$ & $\mathbf{0 , 1 1}$ \\
& Low & 11 & 7,18 & 1,66 & 11,36 & 1,96 & 0,18 & 0,08 \\
& Medium & 15 & 7,67 & 2,13 & 13,07 & 2,31 & 0,24 & 0,11 \\
& High & 7 & 7,43 & 1,81 & 14,72 & 2,29 & 0,32 & 0,08 \\
\hline
\end{tabular}

In general, Table 3 shows the mathematical logical thinking ability scores of students in both classes based on overall and the initial mathematical ability categories (low, medium and high) with a mean score of almost the same at pretest. However, after being given different treatment in both classes the mean score of the posttest both based on overall and initial mathematical abilities category (low, medium and high) showed a difference score. Likewise, the enhancement score. In overall, the mean score of enhancement that obtains ASSURE learning model was 0.41 and a conventional class gets mean score of enhancement is 0.24. Meanwhile, based on the initial mathematical ability category (low, medium and high) in both classes shows ranged score from 0.18 to 0.50 . Furthermore, statistical tests are needed to find out which class enhancement of logical thinking ability higher significantly both based on overall and based on the category of initial mathematical abilities category (see Table 4).

Table 4 shows that the enhancement of logical thinking ability based on the overall was obtained sig (1-tailed) value is 0.00 with an interpretation of $\mathrm{H}_{0}$ rejected. That means, the enhancement of students' mathematical logical thinking ability based on overall who obtain ASSURE learning model is significantly higher than students who obtain conventional learning. Furthermore, based on the initial mathematical ability category (low, medium and high) were obtained sig. (1-tailed) values for all categories more than alpha (0.05) so that $\mathrm{H}_{0}$ is rejected. It shows that the enhancement of students' mathematical logical thinking ability who obtain ASSURE learning model is significantly higher than students who obtain conventional learning in all categories of initial mathematical abilities (low, medium and high). Enhancement of students' mathematical logical thinking ability in class who obtain ASSURE learning model is higher because the learning process is required to use learning media such as student worksheets 
whose contents are problems and must enable student involvement. This is suitable for the results of Bozdogan study that student worksheets have a positive effect on students' mathematical logical thinking abilities [23]. To enhancement students' mathematical logical thinking ability, the learning process in the classroom must be focused on student activity and provide problems that have different levels of difficulty [15]. Based on the description it can be said that logical thinking ability can be improved through ASSURE learning model based on overall and based on the category of initial mathematical abilities (low, medium and high).

There are five indicators of the logical thinking ability is makes de conclusions, setting a combination of several variables, analogy, conducting proof and compiling an analysis [24]. The average score of the enhancement logical thinking ability highest is indicator combination of variables in class obtains ASSURE learning model. Meanwhile, the average score of the lowest enhancement is an indicator of proof in class obtains conventional learning.

Table 4. The statistical test results of differences enhancement mathematical logical thinking ability.

\begin{tabular}{cccc}
\hline $\begin{array}{c}\text { Kategori } \\
\text { KMA }\end{array}$ & Test statistic & $\begin{array}{c}\text { Sig.(1- } \\
\text { tailed })\end{array}$ & Interpretation \\
\hline Overall & Mann-Whitney test & 0,000 & $\mathrm{H}_{0}$ rejected \\
Low & t-test & 0,002 & $\mathrm{H}_{0}$ rejected \\
Medium & t-test & 0,016 & $\mathrm{H}_{0}$ rejected \\
High & Mann-Whitney test & 0,013 & $\mathrm{H}_{0}$ rejected \\
\hline
\end{tabular}

\subsection{Habits of Mind}

The following are descriptive data on the results of students' habits of mind (see Table 5). Table 5 shows the mean scores of students' mathematical habits of mind after being given treatment in both classes. Mean score of the ASSURE class is higher than the average score of the conventional class. Furthermore, statistical tests are needed to find out the students' mathematical habits of mind is significantly better between both class (see Table 6).

Based on Table 6, obtained that sig. (1-tailed) value is 0.048 less than $\alpha(0.05)$ so $\mathrm{H}_{0}$ is rejected. That means students' habits of mind who obtain ASSURE model learning is better than students who obtain conventional learning. ASSURE learning models are required to use learning media, one of which is a student activity sheet. On the activity sheet, students are given problems and solve them by discussing and using other media so that the process of thinking in solving problems and students' habits of mind is trained. Students' habits of mind will be formed if students are faced with challenging problems, provide a lot of skills training, experience attitudes and interests of students who can develop their thinking so that students habits become thinking accustomed $[25,26]$. There are sixteen indicators habits of mind namely persisting, managing impulsivity, listening with understanding and empathy, thinking flexibility, thinking about thinking (metacognition), striving for accuracy, questioning and posing problem, applying past knowledge to new situations, thinking and communicating with clarity and precision, gathering data through all senses, creating, imagining and innovating, responding with wonderment and awe, taking responsible risks, finding humor, thinking interdependently, dan remaining open to continuous learning [12]. The highest average score of habits of mind is on the indicators of listening with understanding and empathy of $64.54 \%$ in the class that obtain ASSURE learning model. The lowest average score of habits of mind is on the existing indicator of $45.8 \%$ in the class that obtain conventional learning. Overall students habits of mind who 
obtain ASSURE learning model is low. However, it is still higher than in the conventional class. This is because habits of mind are the highest level of educational outcomes which oversees other levels of educational outcomes, such as cognitive tasks that require thinking ability, thinking skills, and the lowest level is material [12]. So, to develop habits of mind requires a longer time and must have more experience.

Table 5. The description of students' habits of mind.

\begin{tabular}{cccc}
\hline Class & $\begin{array}{c}\text { Number of } \\
\text { students }\end{array}$ & Mean (\%) & SD \\
\hline ASSURE & 30 & 55,01 & 4,23 \\
PK & 33 & 52,61 & 5,25 \\
\hline
\end{tabular}

Table 6. The test statistic habits of mind score.

\begin{tabular}{cccc}
\hline Test statistic & $\mathrm{Z}$ & $\begin{array}{c}\text { Sig.(1- } \\
\text { tailed })\end{array}$ & interpretation \\
\hline Mann-Whitney & $-1,665$ & 0,048 & $\mathrm{H}_{0}$ rejected \\
\hline
\end{tabular}

\section{Conclusion}

Based on overall and high initial mathematical abilities, the enhancement of students' mathematical creative thinking abilities who obtain ASSURE model learning was significantly higher than students who obtain conventional learning. Meanwhile, based on low initial mathematical ability and medium shows no significantly higher. Based on overall and initial mathematical ability (low, medium and high) the enhancement of students' logical thinking ability who obtain ASSURE model learning was significantly higher than students who obtain conventional learning. Students habits of mind who obtain ASSURE learning model is significantly better than students who obtain conventional learning.

Acknowledgments. The author would like to thank Mr. Supendi as a mathematics teacher at junior high school 4 Lembang, West Bandung who has provided a lot of assistance so that the author can complete this study.

\section{References}

[1] Coraza, G.E., dan Agnoli, S.: Multidisciplinary Contributions to The Science of Creative Thinking. Nanyang Technological University, Singapore: Springer (2016)

[2] Surya, M. Strategi Kognitif dalam Proses Pembelajaran. Bandung: Alfabeta (2015)

[3] Evans, J R \& McKinney J M.: The Modeling Process and Creative Thinking. International Journal of Mathematical Education in Science and Technology. 18:1, 1-8 (2006)

[4] Munahefi, D N., Waluya, S B., \& Rochmad.: Analysis of creative mathematic thinking ability in problem based learning model on self-regulation learning. J. Phys.: Conf. Ser. 983012161 (2017)

[5] Istiqomah, A., Perbowo, K.S., \& Purwanto, S.E.: Promoting Middle School Students' Mathematical Creative Thinking Ability Using Scientific Approach. J. Phys.: Conf. Ser. 948012032 (2018) 
[6] Ersory, E and Baser, N.E.: The Effects of Problem-Based Learning Method in Higher Education in Creative Thinking. Procedia - Social and Behavioral Sciences 116 ( 2014 ) 3494 - 3498 (2013)

[7] Ningsih, Y.P.: Peningkatan Kemampuan Berpikir Logis dan Kreatif Matematis, Serta Self-Efficacy Siswa Melalui Model Pembelajaran Generatif (Generatif Learning). Tesis. Sekolah Pascasarjana Universitas Pendidikan Indonesia, Bandung (2018)

[8] Machdalena.: Peningkatan kemampuan berpikir kritis, kreatif dan self-efficacy matematis siswa melalui model think-talk-write berbantuan geogebra. Tesis. Sekolah Pascasarjana Universitas Pendidikan Indonesia, Bandung (2018)

[9] Pezzuti, L., Artistico, D., Chirumbolo, A., Picone, L., \& Dowd, S.M.: The Relevance of Logical Thinking and Cognitive Style to Everyday Problem Solvig Older Adults. Elsevier: Learning and Individual Differences 36 (2014) 218-223 (2014)

[10] Usdiyana, D., Purniati, T., Yulianti, K., \& Harningsih, E.: Menignkatkan Kemampuan Berpikir Logis Siswa SMP Melalui Pembelajaran Matematika Realistic. Jurnal Pengajaran MIPA Vol 13 No 1 (2009)

[11] Andriawan, B \& Budiarto, M.T.: Identifikasi Berpikir Logis Dalam Pemecahan Masalah Matematika Pada Siswa Kelas VII-1 SMP Negeri Sidoarjo. Jurnal Ilmiah Pendidikan Matematika:UNESA. Volume 2 No 2 Tahun 2014 (2014)

[12] Costa, A.L \& Kallick, B.: Belajar dan Memimpin dengan 'Kebiasaan Pikiran' 16 Karakter Penting untuk Sukes. Jakarta Barat: PT Indeks (2012)

[13] Dwirahayu, G., Kustiawati, D., \& Bidari, I.: Corresponding Habits of Mind and Mathematical Ability. J. Phys.: Conf. Ser. 895012013 (2017)

[14] Septianawati, T.: Peningkatan Kemampuan Pemecahan Masalah Matematis dan Habits of Mind Siswa SMP melalui Model Pembelajaran Process Oriented Inquiry Learning (POGIL). Tesis. Sekolah Pascasarjana Universitas Pendidikan Indonesia, Bandung (2017)

[15] Ash-Shiddieqy, M.H., Suparmi, A., \& Sunarno, W.: The Effectiveness of Module Based On Guided Inquiry Method To Improve Students' Logical Thinking Ability. Journal of Physics: Conference Series, 1006, 012001 (2018)

[16] Hasratudin.: Meningkatkan Kemampuan Berpikir Kreatif Siswa SMP Melalui Pendekatan Matematika Realistic. FMIPA Unimed. Jurnal Pendidikan Matematika, Vol. 4 No.2 (2010)

[17] Sundayana, R., Herman, T., Dahlan, J.A., \& Prahmana, R C I.: Using ASSURE Learning Design To Develop Student's Mathematical Communication Ability. World Transactions on Engineering and Technology Education $\square 2017$ WIETE Vol.15, No.3 (2017)

[18] Smaldino, S.E., Lowther, D.L., \& Mims, C.: Instructional Technology and media for learning. Pearson Merril, Prentice Hall, Upper Saddle River, New Jersey Columcus Ohio (2006)

[19] Idris, N dan Nor, N D.: Mathematical Creativity: Usage of Technology. Elsevier. Procedia Social and Behavioral Sciences 2 (2010) 1963-1967 (2010)

[20] Freiman, V \& Tassell, J. L.: Creativity and Technology in Mathematics Education. Switzerland: Springer International Publishing (2018)

[21] Kuncorowati, R. H., Mardiyana., \& Saputro, D.R.S.: Mathematics Creative Thinking Levels Based On Interpersonal Intelligence. IOP Conf. Series: Journal of Physics: Conf. Series 943 (2017) 012005 (2017)

[22] Bringula, R.P., Bassa, R.S., Cruz, C.D., \& Rodrigo, M.M.T.: Effects of Prior Knowledge in Mathematics on Learner-Interface Interactions in a Learning-by-Teaching Intelligent Tutoring System. SAGE. Journal of Educational Computing Research. 0(0) 1-21 (2015)

[23] Sezen, N \& Bulbul, A.: A Scale on Logical Thinking Abilities. ScienceDirect. Procedia Social and Behavioral Sciences 15 (2011) 2476-2480 (2011)

[24] Sumarmo, U., Hidayat, W., Zukarnaen, R., Hamidah., \& Sariningsih, R.: Kemampuan dan Disposisi Berpikir Logis, Kritis dan Kreatif Matematik (Eksperimen Terhadap Siswa SMA Menggunakan Pembelajaran Berbasis Masalah dan Strategi Think Talk Write). Jurnal Pengajaran MIPA, Volume 17 Nomor 1, April 2012. Halaman 17-33. ISSN 1412-0917 (2012)

[25] Wiles, P.: Folding Corners of the Habits of Mind. NCTM. Mathematics Teaching in the Middle School. Vol.19. No.4 (2013) 
[26] Ningsih, D.R.: Penerapan Model Electing Activities untuk Meningkatkan Kemampuan Pemecahan Masalah Matematis dan Habits of Mind Siswa Sekolah Menengah Pertama. Tesis. Sekolah Pascasarjana Universitas Pendidikan Indonesia, Bandung (2018) 